The University of San Francisco

USF Scholarship: a digital repository @ Gleeson Library |

Geschke Center

Economics

College of Arts and Sciences

1999

\title{
Credit Access, Human Capital and Class Structure Mobility
}

Bruce Wydick

University of San Francisco,wydick@lucas.usfca.edu

Follow this and additional works at: http://repository.usfca.edu/econ

Part of the Economics Commons

\section{Recommended Citation}

Bruce Wydick. Credit access, human capital and class structure mobility. The Journal of Development Studies. Volume 35, Issue 6, 1999. DOI: $10.1080 / 00220389908422605$

This Article is brought to you for free and open access by the College of Arts and Sciences at USF Scholarship: a digital repository @ Gleeson Library | Geschke Center. It has been accepted for inclusion in Economics by an authorized administrator of USF Scholarship: a digital repository @ Gleeson

Library | Geschke Center. For more information, please contact repository@usfca.edu. 


\title{
Credit Access, Human Capital, and Class Structure Mobility
}

\author{
W. BRUCE WYDICK
}

This paper examines the impact of microenterprise credit programs on class structure mobility in developing countries. The paper develops a model that endogenously generates an eight-fold class structure. Class membership is determined by optimal choice of labour activity, which is a function of access to credit and human capital endowments. Predictions from the model suggest that better access to credit will foster upward class mobility among self-employed entrepreneurs, and that this upward class mobility will be accentuated among entrepreneurs with high levels of human capital. Theoretical predictions from the model are compared with data on class structure mobility collected firsthand in western Guatemala. Empirical results show that upward class structure mobility increases substantially with access to credit, and also suggest that the combined effect of innate entrepreneurial ability and credit access has a greater impact on upward class structure mobility than the interaction between formal schooling and credit access.

Bruce Wydick is an assistant professor at the University of San Francisco. The author would like to thank George Akerlof, Pranab Bardhan, David Card, Alain de Janvry, Ethan Ligon, Betty Sadoulet, participants in seminars at the University of California at Berkeley, and the directors of FUNDAP in Quetzaltenango, Guatemala for their helpful comments, suggestions, and encouragement. Financial support for field research by the Mellon Foundation is gratefully acknowledged. 


\section{INTRODUCTION}

The well-documented success of microenterprise credit programs in recent years has led to an explosion of interest in their use as a tool for alleviating poverty and generating economic growth in both developing and transitional economies. ${ }^{1}$ Evidence of this unbridled enthusiasm for such programs occurred at a summit on microenterprise lending sponsored by the Clinton Administration in January 1997. At this summit a consortium of international aid agencies, commercial banks, and governmental authorities agreed on a plan to direct $\$ 23.6$ billion toward providing access to credit to 100 million impoverished households by the year $2005 .^{2}$ While numerous statistics have been compiled regarding the impressive participation and repayment rates realised of many microenterprise lending programs, there is a critical need for research that examines the changes in economic behaviour of loan recipients after they obtain access to this credit. This paper seeks to make a contribution in this area by examining the impact of newfound access to credit on the class structure mobility among loan recipients. Specifically, this paper develops a model which predicts potential differences in upward class structure mobility between loan recipients with different levels of human capital. It then compares the predictions from the model with data showing the class mobility of 358 entrepreneurs in western Guatemala after the introduction of microenterprise lending within the region.

Though some may have eschewed an economic analysis of class structure

mobility for its roots in Marxist ideology, ${ }^{3}$ policy makers concerned with developing and transitional economies have ample reason to share much of this literature's concern over the apparent immutability of class structures in many nations. The perpetuation of stark 
divisions between social classes--between large holders of capital and wage earners, between salaried professionals and the unemployed--may have negative impacts on societal welfare for a number of reasons: The first and perhaps most obvious is the societal tension and political destabilisation that results as wage earners organise against owners of capital in conflict over shares of value-added created in the production process. A class structure consisting of a few large holders of capital is also likely to foster the emergence of monopolies and forestall the benefits that accrue from competition between large numbers of enterprises. The new growth theory has brought to light an additional benefit of an economy characterised by broadly-based capital holdings and large numbers of firms: Innovation and the creation of new ideas and techniques are now seen as a central cause of economic growth [Romer, 1990]; in a competitive economy characterised by a large number of entrepreneurs, such innovation may be more likely to occur. Finally, given the potential for moral hazard in the workplace, the hierarchical structure of a large firm creates a principal-agent network of immense complexity, as well as significant welfare losses in the form of supervision costs. In contrast, a selfemployed entrepreneur whose output directly enters his own utility function does not require supervision or incentives to attain an optimum level of work effort. ${ }^{4}$

Roemer [1982] was the first to build a model which endogenously derived a class structure in a capitalist economy based on unequal distribution of capital. Applying Roemer's model to a sample of five hundred villages in West Bengal, Bardhan [1982] showed that a class structure similar to that depicted by Roemer could be found within rural Indian society. ${ }^{5}$ 
Eswaran and Kotwal [1986] add an additional dimension to Roemer's model: imperfect information in the form of monitoring costs. In their model of agrarian class structure, they assume that capitalists (agricultural landholders) must supervise their workers, who prefer leisure to labour, and therefore have an inherent tendency to shirk. They achieve class formation as a function of access to physical capital, and from the non-substitutability of hired labour for own labour. For example, a self-cultivator (middle class) refrains from hiring a wage labourer at the point when the marginal productivity of labour on his plot equals the going wage rate because the time-cost of supervision by the self-cultivator must be added to the direct cost of hired labour.

The theoretical portion of this research begins in the framework of Eswaran and Kotwal [1986], but adds to their work by suggesting that class structure is not determined by physical capital alone, but by the combined interaction of physical and human capital. Recent sociological analyses of class structure such as Wright [1997] have begun to place an increasing emphasis on human capital as a determinant of class membership. The inclusion of human capital in the analysis of class structure in developing countries has become more important in recent decades. Centuries or even decades ago, ownership of large amounts of land or capital may have constituted a necessary and sufficient condition for membership in an upper class. Today, however, income-generating potential is increasingly characterised by an individual's ability to interact with modern technology and ideas. Clearly this ability is a function of the human capital embodied in a worker's labour.

Further motivation for including human capital rather than only physical capital or land in a model of class structure is its increasing importance in light of the heavy 
migration to the large urban areas in developing countries. The urban share of the Third World's population tripled in the middle half of the 20th century, increasing from 9.3 per cent in 1925 to 28.0 per cent in 1975 [J. Williamson, 1988]. Especially in an urban context, human capital may be equally important a determinant of income-generating capability as physical capital. Thus, relative to the previously cited works that place their analysis of class structure in an agrarian context, this analysis of class structure is applicable to a more general and more modern developing country environment.

The first theoretical result of this research is that class structure mobility increases significantly with the provision of access to credit. Access to credit has this effect since through enterprise capitalisation, it changes an agent's optimal mode of labour activity. For example, theoretical results of this research show that access to credit fosters movement out of self-employment and into labour supervision. This result is confirmed by first-hand survey data on class structure mobility collected in conjunction with FUNDAP, a microenterprise credit program operating in western Guatemala. As a result, empirical results from the Guatemalan survey data corroborate hypotheses developed in the present paper and in previous work with respect to the positive effect of expanded access to credit on upward class structure mobility.

Additional results of the paper focus on effect of human capital in the form of formal schooling on class structure mobility. Theoretical results derived in this paper predict that individuals with higher levels of human capital will expand employment within their enterprises more rapidly if more human capital lowers the time cost of supervision and administration in an enterprise. However, there are different components to human capital. While one component of an entrepreneur's human capital comes from 
innate managerial ability, another component of an entrepreneur's human capital comes in the form of formal schooling. Formal skills such as reading, writing and solving mathematical problems are likely to augment an entrepreneur's innate managerial skills to increase managerial efficiency.

Interestingly, the Guatemalan data used in this study suggest that it is these lessmeasurable characteristics of managerial ability rather than formal schooling which interact with access to credit to foster upward class mobility. These characteristics of human capital are difficult to identify, but may include personal attributes such as Schumpeterian entrepreneurial drive, technical expertise within a given area of business, or strong relational skills.

The rest of this chapter is organised as follows: Section II develops a model from which membership by all agents in the economy in one of eight classes is endogenously derived from a vector of exogenous physical and human capital endowments, $(h, k)$. Section III considers how membership within the class structure might change if agents gain expanded access to credit from a microenterprise lending institution. Section IV presents data on class structure mobility obtained first-hand through a credit survey carried out by this researcher of 358 small businesses owners in western Guatemala. Section V provides conclusions of the research and policy recommendations for targeted credit programs in developing countries.

\section{A MODEL OF ENDOGENOUS CLASS STRUCTURE FORMATION}

Following the general framework of Eswaran and Kotwal [1986], this paper presents a partial equilibrium model of an economy of utility-maximising agents. These agents are 
constrained by time and by their endowments of physical and human capital. Utility is given, for simplicity, in additive form as a function of income and leisure:

$$
U(Y, \ell)=Y+v(\ell)
$$

with $v^{\prime}(\ell)>0, v^{\prime \prime}(\ell)<0, v^{\prime}(0)=\infty$, and $v^{\prime}(1)>0$. All agents have identical preferences over leisure. The fact that utility is a linear function of income implies that all agents in the economy are risk-neutral.

Production is given as a function of capital used in production, $K$, (which may include land) and total efficiency units of labour, $N$.

$$
q=\theta F(K, N)
$$

The production function is linear homogeneous. Derivatives of the function exhibit the normal conditions: $F_{N, K}()>0,. F_{N N, K K}()<$.0 , and $F_{N K}()>$.0 . The symbol $\theta$ represents a random shock with mean equal to one, which is intended to model uncertainty in production of the agent's enterprise. Because of this uncertainty, it is impossible for the owner of the enterprise to determine the amount of effort employed by hired workers. The market price of output is set equal to one.

The productivity of a worker is a function of the level of his human capital, $h$. This productivity is measured in efficiency units. ${ }^{6}$ The number of efficiency units of labour applied to production in an enterprise is composed of the efficiency units of an entrepreneur's own labour, $x$ plus that from the labour of hired workers, $z$. Human capital is distributed as an endowment across the economy to all agents $i$ such that $h_{i} \in[\underline{h}, \bar{h}]$. $^{7}$

Efficiency units of an agent's labour are given by $x=\phi\left(h_{i}\right)$, where $\phi(\cdot)$

transforms an agent's human capital into efficiency units with $\phi^{\prime}\left(h_{i}\right)>0$. The number of 
efficiency units hired by an enterprise in this model is generally given by $z=\sum_{j=1}^{n} \phi\left(h_{j}\right)$, the sum of the number of hired workers, $n$, adjusted for the $j^{\text {th }}$ employed worker's level of human capital. For simplicity, it is assumed that firms hire workers who are of a homogenous level of human capital $h_{j}$. The total number of efficiency units employed by the firm, $N$, is then equal to

$$
N=x+z=\phi\left(h_{i}\right) L+n \phi\left(h_{j}\right)
$$

where $L$ is the fraction of an agent's time labouring in her own enterprise.

A larger stock of human capital has three beneficial effects for an agent:

(1) It increases the efficiency units of some agent $i$ labouring in his own firm by $\phi^{\prime}\left(h_{i}\right)$.

(2) It lowers labour supervision costs by making agents better managers of employed labour. (3) It increases the wage for the agent in the labour market. Wages are a positive function of human capital, less a fixed supervision cost for all workers. These are embodied in the wage function $w\left(h_{i}\right)$, and $w^{\prime}(h)>0$.

Time costs of supervision are given as a function of the supervising agent's human capital, ${ }^{8}$ and as a function of the number of wage labourers hired, or

$$
s=s(h, n)
$$

where $s_{n}(h, n)>0, s_{h}(h, n)<0, s_{n h}(h, n)<0$, and $s_{n n}(h, n)>0$. The convexity of the supervision function limits the scope of an enterprise despite linear homogeneity in production.

Each agent is constrained by one unit of time in each period. This time can be spent working in the agent's own enterprise, $L$, supervising hired labour, $s$, in outside 
wage employment, $L_{\mathcal{W}}$, or enjoying leisure, $\ell$. Thus the time constraint for each agent in the economy can be written as

$$
L_{w}+L+s(h, n)+\ell=1
$$

Each agent is endowed with a fixed amount of capital $\hat{k}$ and a line of credit equal to $B$. Added together, these equal $k$, the total amount of working capital available to the agent. The capital $\hat{k}$ can be leased on the market at an interest rate $r$ or used as capital in production, $K$. As in the model of Eswaran and Kotwal, it is assumed here that all working capital outlays are incurred at the start of the production period. In other words, an agent is unable to use future profits from his enterprise as collateral against a loan. The capital constraint faced by all agents is thus

$$
r(\hat{k}-K)+w\left(h_{i}\right) L_{w}-n w\left(h_{j}\right)+B \geq 0
$$

The capital constraint shows that net proceeds (costs) from leasing out (leasing) land added to wage income plus net borrowing must be greater than or equal to the total wages paid for hired labour. In practice we would expect $B$ to be highly correlated with $\hat{k}$ because of the need for loans to be collateralised. For simplicity, the option of financing production from past savings is excluded in this analysis.

By substituting equations (2) through (5) into (1), making them subject to the working capital constraint given in (6), and constraining $L_{\mathcal{W}}, L, n \geq 0$, we obtain the following maximisation problem for each agent in the economy: 


$$
\begin{aligned}
& \max _{L_{w}, L, n, K, \lambda} U=F\left(K, \phi(h) L+n \phi\left(h_{j}\right)\right)+w(h) L_{w}+r \hat{k}-n w\left(h_{j}\right)-r K \\
& +v\left(1-L_{w}-L-s(h, n)\right)+\lambda\left(r(\hat{k}-K)+w(h) L_{w}-n w\left(h_{j}\right)+B\right)
\end{aligned}
$$

where $\lambda$ is the Lagrangian multiplier. ${ }^{9}$ Differentiation of the maximisation problem in (7) yields the first-order conditions of (8) through (12):

$$
\begin{aligned}
& U_{L_{w}}: w(h)(1+\lambda)-v^{\prime}(\ell)=0 \\
& U_{L}: F_{x}(K, N) \phi(h)-v^{\prime}(\ell)=0 \\
& U_{n}: F_{z}(K, N) \phi\left(h_{j}\right)-w\left(h_{j}\right)(1+\lambda)-s_{n}(h, n) v^{\prime}(\ell)=0 \\
& U_{K}: F_{K}(K, N)-r(1+\lambda)=0 \\
& U_{\lambda}: r(\hat{k}-K)+w(h) L_{w}-n w\left(h_{j}\right)+B=0
\end{aligned}
$$

These equations provide the framework for determining the labour activities of individual agents given their exogenous endowment $(h, k)$. There exists a unique utilitymaximising labour activity vector for each agent, given her capital endowment $(h, k)$ and the exogenous parameters of the model. In this analysis, like the Roemer and EswaranKotwal models, we have allowed three possible means of income generation: employment as a wage earner, working as a self-employed labourer, and hiring and supervising outside labour for work in one's own enterprise. In utility-maximising equilibrium, each agent will optimally choose to engage in some combination of these different modes of labour activity.

The model thus generates the following eight possible combinations of labour activity for any agent, and their corresponding classes: 
(II) $\left(L_{w}, 0,0\right)$ Wage Earner

(III) $\quad\left(L_{W}, L, 0\right)$ Credit-Constrained Entrepreneur

(IV) $(0, L, 0)$ Self-Employed Entrepreneur

(V) $\quad(0, L, s)$ Small Enterprise Owner

(VI) $\quad\left(L_{\mathcal{W}}, L, s\right)$ Entrepreneurial Wage Earner

(VII) $\left(L_{\mathcal{W}}, 0, s\right)$ Capitalist Professional

(VIII) $(0,0, s)$ Large Capitalist

The optimality conditions derived from (7) determine how agents will sort themselves out among these eight possible classes. A mapping of these classes in the space of the endowment vector $(h, k)$ is provided in Figure 1:

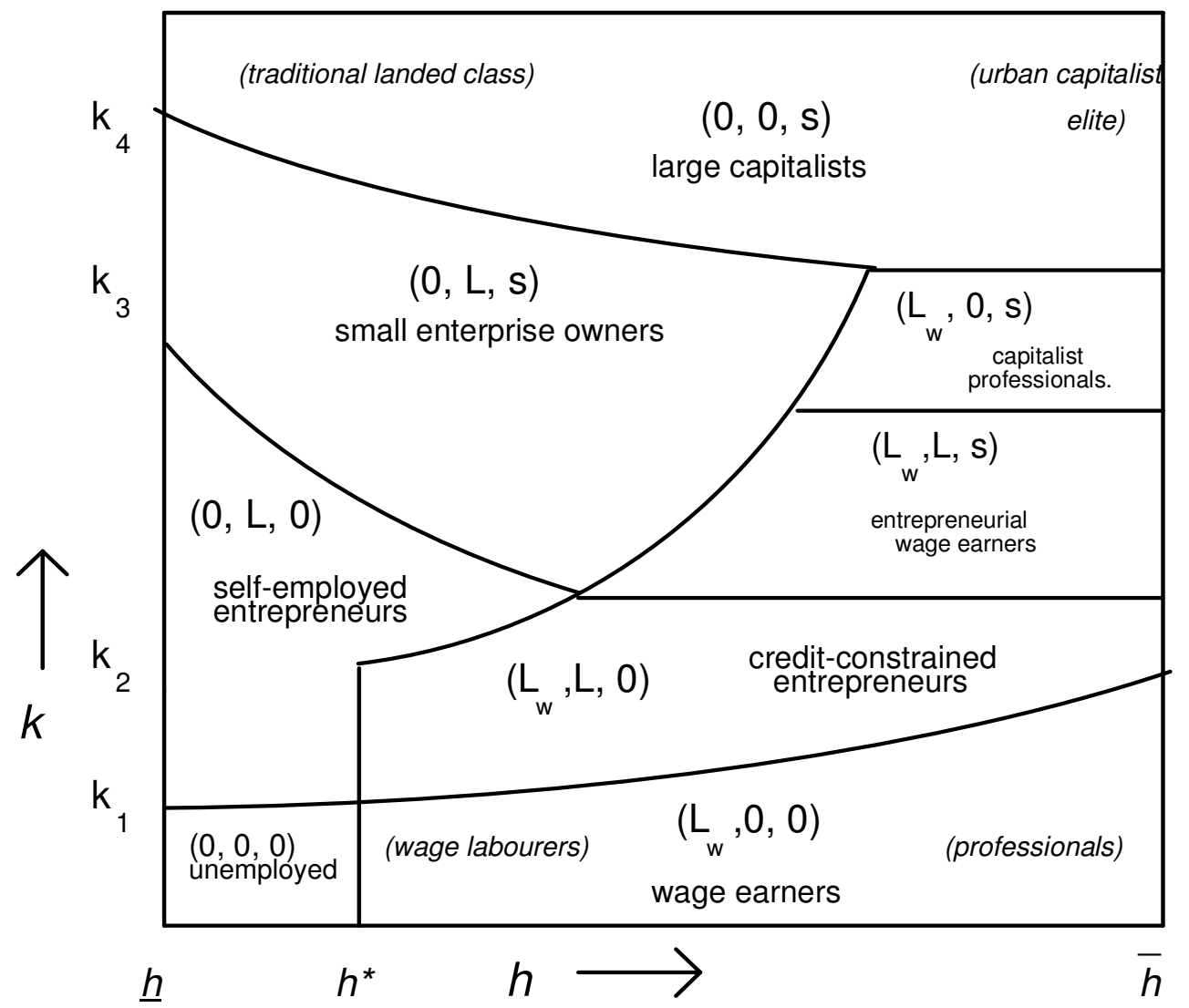

Figure 1: Class Structure Map 
The complete mathematical proof of the class boundaries derived in the class structure map will not be given here, but is provided in Wydick [1996]. However, the intuition for the shape of the boundaries is the following: The boundaries upon which an agent is indifferent between self-employment and labour supervision are downwardsloping, since increases in either human capital or physical capital will make hiring in labour more attractive. Determining the slope of other boundaries requires assumptions on the relative effects of increases in human capital on different labour activity. In the class structure map in given in Figure 1 we assume that boundaries that separate wage activity and self-employment are upward-sloping as fixed supervision costs stemming from issues of moral hazard are likely to greatly reduce wages for low human capital agents, while agents with high levels of human capital would be able to command a premium wage in the labour market. Thus we would expect that holding $k$ fixed, increasing levels of $h$ would induce labour market activity at the expense of selfemployed labour activity. The relative effects of human capital on the return to wage labour and on labour supervision are more difficult to discern. In Figure 1 we assume that increases in human capital have a neutral effect between reducing labour supervision costs and increasing wages. These latter assumptions, however, are not critical to the central analysis in this paper which will focus on the effect of increases in $k$ to move individuals out of labour market activity and into entrepreneurial activity, and the combined affects of $h$ and $k$ in moving individuals from self-employment into labour supervision.

Note that in contrast to previous models, this formulation generates a class of unemployed agents possessing physical and human capital that is so low $\left(k_{l}\right.$ at $\left.\underline{h}\right)$ that the 
return to non-labour activity exceeds the return to any of the three types of labour activity. The boundaries for other classes begin at $k_{2}$ through $k_{4}$, at $\underline{h}$ and reflect an optimal allocation of labour activity given any endowment of $h$ and $k$.

\section{THE IMPACT OF ACCESS TO CREDIT ON CLASS MEMBERSHIP}

Substantial barriers in credit markets exist in developing countries that substantially inhibit capital accumulation in the informal sector. Formal lending institutions have a lamentable record of channeling credit to the poor in LDCs [World Bank, 1989]. The primary reasons are asymmetric information barriers between borrowers and lenders which give rise to adverse selection and moral hazard problems in credit markets, and the high administrative costs to lenders for small loans [Stiglitz, 1990]. This combination of prohibitively high monitoring costs per loan and requirements for collateral prohibit a vast number of entrepreneurs from taking small loans in formal financial markets. As development institutions have recognised the dire implications of these credit constraints on economic growth, there has been in recent years an explosion of credit programs in developing countries, targeting credit at those shut out of formal financial markets.

The analysis in the remainder of this paper will focus on two possible policy goals of credit expansion: (A) the effect of microenterprise lending on moving agents out of the class of credit-constrained entrepreneurs $\left(L_{\mathcal{W}}, L, 0\right)$ into full-time entrepreneurial activity in the form of $(0, L, 0)$ and $(0, L, s)$; and (B) the combined interaction of microenterprise lending with the formal schooling component of $h$ on movement into labour supervision, or from $(0, L, 0)$ to $(0, L, s)$ and $(0,0, s)$. 


\section{A. Credit-Constrained Entrepreneurs}

The class of credit-constrained entrepreneurs $\left(L_{\mathcal{W}}, L, 0\right)$ are clearly one of the groups of individuals most likely to benefit from a credit expansion program. Movement of $\left(L_{\mathcal{W}}, L, 0\right)$ into $(0, L, 0)$ through credit expansion is a worthy policy goal since it reduces the efficiency loss from moral hazard in wage labour, and also may improve income distribution by increasing the return to self-employed labour. A relevant policy question is the extent to which better access to credit allows credit-constrained entrepreneurs to become fully self-employed. Therefore, the first analysis of the Guatemalan data will be to determine if sufficient increases in credit expansion allow agents in the class of credit-constrained entrepreneurs to move into the class of selfemployed entrepreneurs. This will not only provide a test of hypotheses developed in this paper (as seen in Figure 1), but also those previously put forth be Roemer [1982] and Eswaran and Kotwal [1986].

\section{B. Employment Generation in the Informal Sector}

A primary goal of development policy makers involved in microenterprise lending has been to stimulate job creation in impoverished regions through capitalisation of the informal sector. Such a policy is designed to stimulate the demand for labour in such areas, creating new employment, while putting upward pressure on the wage rate.

A question then emerges: to what type of individual should credit be expanded to be consistent with this policy? The prediction from the model is that sufficient increases in credit expansion will facilitate class structure mobility from $(0, L, 0)$ to $(0, L, s)$ and 
from $(0, L, s)$ to $(0,0, s)$. Furthermore, as seen in Figure 1, fluidity of movement between these classes will be positively affected by the level of human capital of the agent, i.e. the class boundaries between $(0, L, 0) /(0, L, s)$, and $(0, L, s) /(0,0, s)$ are downwardsloping in $(h, k)$ space. The intuition behind this is the following: With an agent, for example, on the boundary of $(0, L, 0) /(0, L, s)$, a slight increase in human capital endowment will make it marginally less costly to monitor a hired employee in terms of the opportunity cost of the agent's time. A slight increase in physical capital endowment or credit makes any potential hired labour marginally more productive, and thus induces the agent to hire more labour.

However, it is almost tautological to argue that, after expanding credit access, we should observe agents with greater human capital expanding employment within their enterprises at a greater rate than those with lower levels of human capital. As noted previously, there are more easily measurable components to human capital such as years of formal schooling, and less measurable components such as technical know-how, entrepreneurial drive, and personnel management skills. What is most interesting and relevant in terms of policy implications is to focus on the more easily measurable component of human capital, formal schooling, to determine if this component of human capital that is observable to microenterprise lending institutions interacts with increased credit access to expand employment creation in informal sector enterprises. If true, this would have important implications for microenterprise lending policy in the informal sector. To maximise the increase in demand for labour in a region, loans could be targeted at those in the informal sector with higher levels of formal education. If this hypothesis is not confirmed by the data, microenterprise programs may be able to meet 
these goals just as easily by granting loans to those who may even be illiterate and struggle with the most basic mathematical skills, but are strong in the less measurable components of human capital mentioned above.

\section{THE GUATEMALAN DATA}

During the summer months of 1994 I designed and helped carry out first-hand survey of 358 entrepreneurs in western Guatemala, primarily in and around the rural towns of Quetzaltenango (population 96,000) and Totonicapan (population 9,000). Of the 358 entrepreneurs interviewed in the survey, 236 were participants in a credit program operated by FUNDAP, a Guatemalan credit institution operating in the region that provides credit to small businesses. The remaining 122 entrepreneurs were interviewed as a control group. These entrepreneurs were located in areas not reached by FUNDAP and were highly credit-constrained. The surveys were administered the entrepreneur's location of business. Within the sample, 258 of the interviewees were productores (light manufacturers) and 100 were commerciantes (retailers).

A classic problem with this kind of analysis is selection bias, i.e. borrowers in the credit program may share personal characteristics which are different than that of the control group. Although it is difficult to control for unobservable characteristics between groups, Table 1 shows that at least the observable characteristics of the control group were quite similar to those of FUNDAP borrowers. ${ }^{10}$ The average age of both groups was approximately 36 years old. Average (pre-credit) monthly sales were approximately US\$371 for FUNDAP borrowers and US\$432 for members of the control group. Average formal education was 3.26 years for FUNDAP borrowers and 4.86 years for 
those in the control group. Thus if differences exist between the control group and the treatment group, it would appear that the control group would be slightly a more educated and higher income group. Of the entire sample interviewed 101 were female and 257 were male, this ratio holding roughly the same for both groups.

The average size of a recipient's initial loan from FUNDAP was the equivalent of US\$115, ranging from a minimum of $\$ 18$ to a maximum in the sample of $\$ 545(\sigma=\$ 61)$. FUNDAP routinely rewards timely repayment by allowing outstanding balances to be rolled over into a subsequent loan and by regular increases in the size of loans.

The positive impact of the loans was obvious by simple examination of the change in gross revenues over time between the businesses with access to credit and those without. The average time that the 236 FUNDAP borrowers had been receiving credits was 2.33 years. Among FUNDAP borrowers, average gross revenues were \$371 per month before receiving loans from FUNDAP, but this figure had increased to $\$ 658$ by the time of the interviews. In contrast, entrepreneurs in the control group realised an increase in average gross revenues from $\$ 432$ per month to only $\$ 452$ per month during the three years before the time of the interview.

While it is possible to argue that such differences could be caused by differences in unobservable characteristics between the treatment and control groups, close examination of the data indicate that this is unlikely. If credit access were not largely responsible for differences in class structure mobility between groups, we would then at least expect to see similarities in changes over time between the most upwardly mobile members of control group and those of the treatment group. However as Table 1 indicates, while the top ten per cent of entrepreneurs in the control group showed a net 
increase in hired labour of 1.9 employees over three years, this average was equaled by roughly the top fifty per cent of the treatment group. Gross sales statistics confirm this phenomenon. While the top ten per cent of the control group increased gross sales over the period in question by 125 per cent, the top ten per cent of the treatment group increased gross sales by 240 per cent. Thus even upon comparing members of both groups who would be most likely to share unobservable characteristics (such as entrepreneurial drive, ambition, etc.) we see significantly higher upward mobility in entrepreneurs with access to credit.

How does the data on class structure mobility compare to the predictions of the model? Tables IA-B to 3A-B illustrate class structure mobility in the treatment group and control groups in a Class Structure Mobility Matrix (CSMM). These tables show class structure mobility among 107 productores in the sample who had been recipients of credit from FUNDAP for two to three years and class structure mobility over three years for another group of 56 productores who were owners of businesses in areas not yet reached by the credit program. Because FUNDAP lends only to entrepreneurs with existing businesses, and because no instances of membership in $\left(L_{w}, 0, s\right)$ were found in the survey, class membership in the sample was limited to the classes $\left(L_{W}, L, 0\right)$, $\left(L_{W}, L, s\right),(0, L, 0),(0, L, s)$, and $(0,0, s) .{ }^{11} \quad$ Table $2 \mathrm{~A}$ presents a CSMM which compares the class mobility of the 107 productores who had access to credit from the lending institution for two to three years up to mid-1994 with a group of 56 productores in Table 2B who had no access to credit during the previous three years.

(Insert Tables 2A and 2B here) 
The greater class mobility by the group of entrepreneurs with access to credit is readily apparent by comparing Tables $2 \mathrm{~A}$ and $2 \mathrm{~B}$. While the largest elements of the CSMM in Table 2B tend to be located on the diagonal, indicating class stagnation, Table $2 \mathrm{~A}$ portrays a relatively dynamic class structure in which the largest elements in each row tend to be located to the right of the diagonal. Comparison between the two tables shows the greater rate at which entrepreneurs with access to credit moved out of part-time wage-earning activity into full-time self-employment than those without credit. The greatest difference between the groups is in mobility between the classes $(0, L, 0)$ and $(0, L, s)$. While the vast majority of those with access to credit moved into laboursupervising activity, only a minority of those without access to credit were able to move out of full-time self-employment. The impact of access to credit on class structure mobility does, however, appear to wane at higher levels of capitalisation. While class movement between $(0, L, 0)$ and $(0, L, s)$ is relativity fluid, mobility between $(0, L, s)$ and $(0,0, s)$ is much less so, perhaps because of diminishing returns to labor or convexity in supervision costs.

The effect of formal schooling on class structure mobility can be seen in Tables 3A-B and 4A-B. The CSMMs presented in Tables 3A-B show the difference in class structure mobility between those with access to credit and the control group among entrepreneurs with four or more years of formal education. Tables 4A-B provide the same analysis of entrepreneurs with less than four years of formal education.

(Insert Tables 3A-B and Tables 4A-B here)

It is interesting to compare class structure mobility between entrepreneurs with four or more years of schooling and those with three or fewer years of formal schooling 
(who both enjoyed access to credit) in the CSMMs in Tables 3A and 4A. Note that the rate of movement into supervisory modes of labour activity was actually greater among the entrepreneurs with less formal education than for the more educated sub-group. Before receiving access to credit, 41.4 per cent of the more educated entrepreneurs were members of $(0, L, s)$ or $(0,0, s)$, and only 34.8 per cent of the less-educated group were members of $(0, L, s)$ and $(0,0, s)$, which is consistent with the class structure map presented in Figure 1. However, at the end of the transition period, 71.2 per cent of the less-educated group were members of these 'higher level' classes, while this was true for only 65.8 per cent of the entrepreneurs with a greater amount of formal education! In addition only one entrepreneur out of fourteen of the more educated group made the transition from $(0, L, s)$ to $(0,0, s)$ (to the 'large capitalist' class), while four out of 23 in the less educated group were able to make the transition.

A study of the tables shows that there also appears to be some degree of substitutability of human capital for physical in class structure mobility. Upward mobility is clearly greater in the CSMM in Table 3B than in Table 4B. Without access to credit, the more highly educated entrepreneurs appear to be able to expand businesses over time at a greater rate than the less-educated entrepreneurs without access to credit. Nevertheless, the Guatemalan data show class mobility among this group to be much less fluid than among the groups with access to credit.

Class stagnation is especially notable in the CSMM in Table 4B, which shows class movement among the less-educated productores without access to credit. Not surprisingly, none of these entrepreneurs begins the period with membership in $(0,0, s)$. 
Moreover, none of the entrepreneurs who begin in the class $(0, L, S)$ is able to transition to $(0,0, s)$ by the end of the three-year period.

More formal testing of the model presented in Section III of this paper was carried out in the form of logit estimations taken on the probability of different measures of upward class structure mobility subject to measures of credit access and a vector of control variables. Table 5 presents two different specifications which test for the effect access to credit and formal education (and the interaction between these variables) on class structure mobility. The specification given in estimations (1) and (3) tests the effect of credit access (represented by a dummy variable) on FUNDAP borrowers who had been provided access to credit for either two or three years relative to changes in class structure mobility of the control group over three years.

The second type of specification, given in estimations (2) and (4), shows the impact of successive years of credit access on class structure mobility. The gradual and sequential implementation of FUNDAP's microenterprise program into different village areas allowed for a kind of natural experiment on the effect of additional years of credit access. FUNDAP borrowers had received access to credit for varying lengths of time. Some households happened to be located in areas in which FUNDAP had carried out lending operations since its foundation in 1988. Other households were located in village areas where FUNDAP had recently initiated lending activity only within the last twelve months. Others were in areas in which the institution had begun lending operations for the period in between. What is more, an important part of FUNDAP's credit policy is to increase a borrower's access to credit at a relatively slow pace over a sequence of loans. Thus FUNDAP's slow and sequential introduction of credit into 
different areas in western Guatemala, combined with its lending policy to its borrowers, provided a valuable instrument, years of credit access, for ascertaining the impact of varying degrees of access to credit. The logit estimations in (2) and (4) are of the form

$$
\log \left(\frac{P_{i}}{1-P_{i}}\right)=\alpha+\beta_{1} k_{i}+\beta_{2} k_{i} h+\psi \boldsymbol{y}_{i}
$$

where $k_{i}$ represents years of credit access, $h_{i}$ represents years of formal schooling, $y_{i}$ is a vector of control variables, $\alpha, \beta_{1}$ and $\beta_{2}$ are estimated parameters, and $\varphi$ is a vector of estimated parameters. Estimated values of $\beta_{1}$ and $\beta_{2}$ are thus intended to capture the effect of credit access and the interaction of credit access with schooling on class structure mobility respectively. Estimations in (1) and (3) substitute a dummy variable for $k_{i}$ to represent credit access. Estimation (5) uses Ordinary Least Squares to ascertain the effect of additional years of credit access on net changes in hired labour.

The logit estimations in (1) and (2) attempt to capture the impact of credit access and formal schooling on movement out wage labour activity $\left(L_{w}\right)$ and into selfemployment. The coefficient on credit access has the correct sign, and would indicate a very plausible 10 per cent increase in probability of moving out of wage labour activity for every additional year of credit access, but is statistically insignificant. Years of formal schooling also appear to have an insignificant effect on movement out of wage labour activity; this may be expected, however, given the high opportunity cost of leaving the often higher-paying jobs associated with more years of formal education.

The estimations in (3) and (4) illustrate the highly significant effect of credit access in moving individual borrowers from self-employment into labour supervision. The estimations are carried out on 107 initially self-employed productores, and show that 
two years of credit access results in a probability increase of 40 per cent of taking on hired labour. Results also are indicative of diminishing returns to years of credit access; the squared term is negative and is statistically significant in estimation (4). Again, formal schooling, if anything, is shown to have a negative effect on adding hired labour to an enterprise--a surprising yet interesting result which points to the importance of the less observable aspects of human capital relative to formal schooling in microenterprise management in developing countries. The coefficient estimations in (5) again point to the beneficial effects of credit access on employment generation in microenterprises. On average, three years of credit access produces a net increase of one full-time position for a hired labourer. Moreover, although results indicate that younger borrowers may be more likely to create employment given access to credit, gender plays no significant role in employment generation. The Guatemalan data indicate that enterprise expansion and upward class mobility is just as prevalent among women with access to credit as among men. Thus the results from this study indicate that, given access to credit, a female entrepreneur with little or no formal education is as likely to add hired labour to an enterprise as a male entrepreneur with substantially higher levels of formal education, and is more likely to increase the scope of her enterprise given greater credit access.

\section{CONCLUSIONS FOR CREDIT POLICY}

This paper has shown that a class structure consisting of eight classes emerges endogenously based on individual endowments of human and physical capital. Class structure mobility as portrayed in the Guatemalan data corroborate the hypothesis developed in this paper and in previous research that demonstrate the positive impact of 
microenterprise lending on class structure mobility. Access to credit clearly appears to foster movement from self-employment to labour supervision, although results in this paper cannot strongly confirm the effect of credit access in moving individuals from wage labour activity into self-employment.

The effect of human capital on the dynamics of class mobility among individuals who have been provided access to credit is more interesting, but somewhat less clear. Formal schooling appears to have very little impact on upward class mobility for smallscale entrepreneurs in Guatemala. Even the interaction between formal schooling, credit access, and upward class mobility is quite weak statistically. We would expect greater levels of human capital to lower supervision and administrative costs so that credit targeted at highly educated entrepreneurs should foster more rapid enterprise growth. However, the Guatemalan data indicate that access to credit seems to unleash an entrepreneurial drive in certain individuals that is independent of formal education. For these individuals supervision costs appear to be relatively flat up to perhaps three or four employees. However, the data also indicate that convexities in supervision costs may kick in shortly after this point, i.e. the data show much more rapid class movement from self-employment to supervision of one to four workers than after this point.

Policy recommendations for development institutions follow from the results of this research. Microenterprise lending institutions should not fear that lending to lesseducated borrowers would stifle their ability to generate employment in the informal sector. A potential caveat to this, however, is that those with more schooling may be more likely to innovate and adopt new technology and ideas, and thus establish enterprises with greater potential for long-term growth. However, the empirical findings 
from the Guatemalan data suggest that in small, informal sector enterprises, formal education is not a good indicator of entrepreneurial human capital. Instead, microenterprise programs should try to target credit at the Schumpeterian entrepreneur, the small-scale manufacturer with practical human resource management and administrative skills, and a predilection for expanding production and reaching into new markets. 
Table 1--Descriptive Statistics

\begin{tabular}{|c|c|c|}
\hline Variable & Control group & treatment group \\
\hline years of credit access & 2.32 & $\mathbf{0}$ \\
\hline $\begin{array}{c}\text { years of formal } \\
\text { education }\end{array}$ & 4.86 & 3.26 \\
\hline age & 37.13 & 36.11 \\
\hline $\begin{array}{l}\text { fraction urban } \\
\text { borrowers }\end{array}$ & 46.57 & 24.05 \\
\hline $\begin{array}{l}\text { fraction male } \\
\text { borrowers }\end{array}$ & 75.34 & 76.89 \\
\hline $\begin{array}{c}\text { Fraction } \\
\text { manufacturers } \\
\end{array}$ & 72.60 & 76.79 \\
\hline \multicolumn{3}{|l|}{$\frac{\text { mean net hired labour }}{\text { added: }}$} \\
\hline --top $10 \%$ & 1.94 & 3.34 \\
\hline --top $20 \%$ & 1.25 & 2.69 \\
\hline --top $50 \%$ & 0.80 & 1.92 \\
\hline \multicolumn{3}{|l|}{$\frac{\text { mean } \% \text { increase in }}{\text { gross sales: }}$} \\
\hline -top $10 \%$ & $125 \%$ & $240 \%$ \\
\hline --top $20 \%$ & $95 \%$ & $150 \%$ \\
\hline --top $50 \%$ & $45 \%$ & $75 \%$ \\
\hline
\end{tabular}

Source: 1994 Guatemala field survey.

Table 2A

Productores with Access to Credit:

Class Mobility over 2-3 Years

Subsequent Class Membership

\begin{tabular}{c|c|c|c|c|c|r}
$\left(L_{w}, L, 0\right)$ & \multicolumn{1}{c}{$\left(L_{\mathcal{w}}, L\right.}$, & $\left(L_{\mathcal{w}}, L\right.$, & $(0, L, 0)$ & $(0, L, s)$ & $(0,0, s)$ & total \\
\hline $\mathbf{1}$ & $\mathbf{3}$ & $\mathbf{1}$ & $\mathbf{5}$ & $\mathbf{0}$ \\
\hline
\end{tabular}




\begin{tabular}{|c|c|c|c|c|c|c|}
\hline Initial & $\left(L_{w}, L, s\right)$ & $\mathbf{0}$ & 3 & 1 & 6 & $\mathbf{0}$ \\
\hline Class & $(0, L, 0)$ & 2 & 2 & 15 & 28 & $\mathbf{0}$ \\
\hline \multirow[t]{3}{*}{ Membership } & $(0, L, s)$ & $\mathbf{0}$ & 1 & 4 & 27 & 5 \\
\hline & $(0,0, s)$ & $\mathbf{0}$ & $\mathbf{0}$ & $\mathbf{0}$ & $\mathbf{0}$ & 3 \\
\hline & total: & 3 & 9 & 21 & 66 & 8 \\
\hline
\end{tabular}

Table 2B

Productores with No Access to Credit:

Class Mobility Over 3 Years

Subsequent Class Membership

\begin{tabular}{|c|c|c|c|c|c|c|c|}
\hline & & $\left(L_{w}, L, 0\right)$ & $\left(L_{w}, L, s\right)$ & $(0, L, 0)$ & $(0, L, s)$ & $(0,0, s)$ & total \\
\hline & $\left(L_{\mathcal{W}}, L, 0\right)$ & 1 & $\mathbf{0}$ & 1 & 2 & $\mathbf{0}$ & 4 \\
\hline Initial & $\left(L_{w}, L, s\right)$ & 1 & 4 & 1 & 1 & $\mathbf{0}$ & 7 \\
\hline Class & $(0, L, 0)$ & $\mathbf{0}$ & 1 & 15 & 6 & $\mathbf{0}$ & 22 \\
\hline Membership & $(0, L, S)$ & $\mathbf{0}$ & 1 & 1 & 16 & 3 & 21 \\
\hline & $(0,0, s)$ & $\mathbf{0}$ & $\mathbf{0}$ & $\mathbf{0}$ & 1 & 1 & 2 \\
\hline & & 2 & 6 & 18 & 26 & 4 & 56 \\
\hline
\end{tabular}

Source: 1994 Guatemala field survey.

Table 3A

Class Mobility of Productores with Four or More Years

of Formal Schooling and with Access to Credit:

Subsequent Class Membership 


\begin{tabular}{|c|c|c|c|c|c|c|c|}
\hline & & $\left(L_{w}, L, 0\right)$ & $\left(L_{\mathcal{w}}, L, s\right)$ & $(0, L, 0)$ & $(0, L, s)$ & $(0,0, s)$ & total \\
\hline & $\left(L_{\mathcal{W}}, L, 0\right)$ & 1 & 2 & $\mathbf{0}$ & 3 & 0 & $\overline{6}$ \\
\hline Initial & $\left(L_{w}, L, s\right)$ & $\mathbf{0}$ & $\mathbf{0}$ & 1 & 1 & $\mathbf{0}$ & 2 \\
\hline Class & $(0, L, 0)$ & $\mathbf{0}$ & 2 & 6 & 8 & $\mathbf{0}$ & 16 \\
\hline \multirow[t]{3}{*}{ Membership } & $(0, L, S)$ & $\mathbf{0}$ & $\mathbf{0}$ & 2 & 11 & 1 & 14 \\
\hline & $(0,0, s)$ & $\mathbf{0}$ & $\mathbf{0}$ & $\mathbf{0}$ & $\mathbf{0}$ & 3 & 3 \\
\hline & & 1 & 4 & 9 & 23 & 4 & 41 \\
\hline
\end{tabular}

Table 3B

Class Mobility of Productores with Four or More Years

of Formal Schooling Lacking Access to Credit:

Subsequent Class Membership

\begin{tabular}{|c|c|c|c|c|c|c|c|}
\hline & & $\left(L_{w}, L\right.$, & $\left(L_{w}, L\right.$, & $(0, L, 0)$ & $(0, L, s)$ & $(0,0, s)$ & total \\
\hline & $\left(L_{w}, L, 0\right)$ & 1 & $\mathbf{0}$ & 1 & 1 & $\mathbf{0}$ & 3 \\
\hline Initial & $\left(L_{w}, L, s\right)$ & 1 & 1 & 1 & $\mathbf{0}$ & $\mathbf{0}$ & 3 \\
\hline Class & $(0, L, O)$ & $\mathbf{0}$ & $\mathbf{0}$ & 7 & 4 & $\mathbf{0}$ & 11 \\
\hline Membership & $(0, L, s)$ & $\mathbf{0}$ & 1 & 1 & 9 & 3 & 14 \\
\hline & $(0,0, s)$ & 0 & $\mathbf{0}$ & $\mathbf{0}$ & 1 & 1 & 2 \\
\hline & & 2 & 2 & 10 & 15 & 4 & 32 \\
\hline
\end{tabular}

Source: 1994 Guatemala field survey.

Table 4A

Class Mobility of Productores with Three or Fewer Years

of Formal Schooling and with Access to Credit:

Subsequent Class Membership 


\begin{tabular}{|c|c|c|c|c|c|c|c|}
\hline & & $\left(L_{w}, L, 0\right)$ & $\left(L_{w}, L, s\right)$ & $(0, L, 0)$ & $(0, L, s)$ & $(0,0, s)$ & $\underline{\text { Total }}$ \\
\hline & $\left(L_{w}, L, 0\right)$ & 0 & 1 & 1 & 2 & $\mathbf{0}$ & 4 \\
\hline Initial & $\left(L_{w}, L, s\right)$ & $\mathbf{0}$ & 3 & $\mathbf{0}$ & 5 & $\mathbf{0}$ & \\
\hline Class & $(0, L, 0)$ & 2 & $\mathbf{0}$ & 9 & 20 & $\mathbf{0}$ & 31 \\
\hline \multirow[t]{3}{*}{ Membership } & $(0, L, s)$ & $\mathbf{0}$ & 1 & 2 & 16 & 4 & 23 \\
\hline & $(0,0, s)$ & $\mathbf{0}$ & $\mathbf{0}$ & $\mathbf{0}$ & $\mathbf{0}$ & $\mathbf{0}$ & $\mathbf{0}$ \\
\hline & & 2 & 5 & 12 & 43 & 4 & 66 \\
\hline
\end{tabular}

Table 4B

Class Mobility of Productores with Three or Fewer Years

of Formal Schooling Lacking Access to Credit:

Subsequent Class Membership

\begin{tabular}{|c|c|c|c|c|c|c|c|}
\hline & & $\left(L_{\mathcal{w}}, L, 0\right)$ & $\left(L_{w}, L, s\right)$ & $(0, L, 0)$ & $(0, L, s)$ & $(0,0, s)$ & $\underline{\text { total }}$ \\
\hline & $\left(L_{w}, L, 0\right)$ & 0 & $\mathbf{0}$ & 0 & 1 & 0 & 1 \\
\hline Initial & $\left(L_{w}, L, s\right)$ & $\mathbf{0}$ & 3 & $\mathbf{0}$ & 1 & $\mathbf{0}$ & 4 \\
\hline Class & $(0, L, 0)$ & $\mathbf{0}$ & 1 & 8 & 2 & $\mathbf{0}$ & 11 \\
\hline \multirow[t]{3}{*}{ Membership } & $(0, L, s)$ & 0 & 0 & 0 & 7 & 0 & 7 \\
\hline & $(0,0, s)$ & $\mathbf{0}$ & $\mathbf{0}$ & $\mathbf{0}$ & $\mathbf{0}$ & $\mathbf{0}$ & $\mathbf{0}$ \\
\hline & & 0 & 4 & 8 & 11 & $\mathbf{0}$ & 23 \\
\hline
\end{tabular}

Source: 1994 Guatemala field survey. 
Table 5--Estimation Results

\begin{tabular}{|c|c|c|c|c|c|}
\hline$\underline{\text { Variable }}$ & 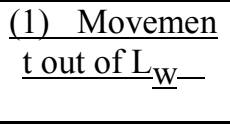 & $\frac{\text { (2) Movemen }}{\text { t out of } \mathrm{L}_{\underline{w}-}-}$ & $\frac{\text { (3) } \text { Movemen }}{\text { t into } S}$ & $\frac{\text { (4) } \text { Movemen }}{\underline{t \text { into } S}}$ & $\frac{\frac{(5)(\mathrm{OLS})}{\text { Net Inc. H. }}}{\underline{\text { Labour }}}$ \\
\hline constant & $1.299 \quad(0.37)$ & $3.169 \quad(1.20)$ & $\begin{array}{r}-0.826 \\
0.69) \\
\end{array}$ & $\begin{array}{r}-1.617 \quad(- \\
1.22) \\
\end{array}$ & $\begin{array}{rr}0.150 & (0.3 \\
9) & \\
\end{array}$ \\
\hline $\begin{array}{c}\text { years of credit } \\
\text { access }\end{array}$ & & $0.454 \quad(0.62)$ & & $\begin{array}{c}1.235 \text { (1.85) } \\
* \\
\end{array}$ & $\begin{array}{l}0.341(2.7 \\
6)^{* * * *}\end{array}$ \\
\hline $\begin{array}{l}\text { years of credit } \\
\text { access squared }\end{array}$ & & $\begin{array}{c}-0.030 \\
0.23)\end{array}(-$ & & $\begin{array}{l}-0.145 \\
(-0.84) \\
\end{array}$ & $\begin{array}{c}-0.030 \\
(-1.73)^{*} \\
\end{array}$ \\
\hline $\begin{array}{l}2-3 \text { years credit } \\
\text { access dummy }\end{array}$ & $1.183(0.37)$ & & $\begin{array}{c}1.097(2.09) \\
* *\end{array}$ & & \\
\hline $\begin{array}{l}\text { years of formal } \\
\text { education }\end{array}$ & $\begin{array}{r}-0.144 \\
0.78)\end{array}$ & $\begin{array}{r}-0.151 \\
0.87)\end{array}$ & $\begin{array}{r}-0.052 \\
0.44)\end{array}$ & $0.067 \quad(0.47)$ & $\begin{array}{rr}0.011 & (0.4 \\
0) & \end{array}$ \\
\hline $\begin{array}{c}\text { years of educ } \times \\
\text { years of credit }\end{array}$ & $\begin{array}{c}0.03 \\
(0.29) \\
\end{array}$ & $\begin{array}{l}\mathbf{0 . 0 2 2} \\
(\mathbf{0 . 2 4}) \\
\end{array}$ & $\begin{array}{l}\mathbf{- 0 . 0 5 2} \\
\mathbf{( - 0 . 9 0 )} \\
\end{array}$ & $\begin{array}{c}-0.126 \\
(-1.69) * \\
\end{array}$ & $\begin{array}{l}-\mathbf{- 0 . 0 0 6} \\
\mathbf{( - 0 . 5 4 )} \\
\end{array}$ \\
\hline age (years) & $\begin{array}{r}-0.028 \\
0.70) \\
\end{array}$ & $\begin{aligned} &-0.032(- \\
&0.86) \\
&\end{aligned}$ & $0.002 \quad(0.07)$ & $0.002 \quad(0.08)$ & $\begin{array}{r}-0.010 \\
1.48)\end{array}$ \\
\hline $\begin{array}{c}\text { urban } \\
\text { borrower (dummy) }\end{array}$ & $0.837 \quad(0.73)$ & $0.092 \quad(0.10)$ & $\begin{array}{l}-0.512 \\
(-0.75)\end{array}$ & $\begin{array}{l}-0.569 \\
(-0.75)\end{array}$ & $\begin{array}{l}\mathbf{- 0 . 1 3 9} \\
(-0.76)\end{array}$ \\
\hline $\begin{array}{c}\text { male } \\
\text { borrower (dummy) }\end{array}$ & $0.099 \quad(0.09)$ & $\begin{aligned}-0.654 & (- \\
0.79) & \end{aligned}$ & $0.227 \quad(0.43)$ & $0.156 \quad(0.29)$ & $\begin{array}{rr}0.089 & (0.6 \\
1) & \end{array}$ \\
\hline $\begin{array}{c}\text { Manufacturer (du } \\
\text { mmy) }\end{array}$ & $\begin{aligned} &-0.649(- \\
&0.37) \\
&\end{aligned}$ & $\begin{array}{r}-1.043 \\
0.63)\end{array}$ & & & $\begin{array}{c}0.71(4.02 \\
) * * *\end{array}$ \\
\hline sample size: & 36 & 53 & 107 & 107 & 171 \\
\hline
\end{tabular}

* Significant at the 10 percent level of confidence

** Significant at the 5 percent level of confidence

*** Significant at the 1 percent level of confidence

Source: 1994 Guatemala field survey.

\footnotetext{
${ }^{1}$ The Grameen Bank, operating in Bangladesh, for example now has a clientele of over 2 million borrowers while boasting a repayment rate of 99 per cent. Muhammad Yunus, the founder of the Grameen Bank now estimates that there are approximately 6 million participants in microenterprise credit programs in developing and transitional economies (National Times, February 1997).

${ }^{2}$ New York Times, January 26, 1997.

${ }^{3}$ The study of class structure has its origins in Marxian dialectical thought. The emergence of a class structure is a well-known a focal point in Marx's analysis of capitalist society (see Marx, Karl. Das Kapital. (1867) Chicago: Gateway, 1970). Later both Lenin and Mao categorised the class divisions they observed
} 
in their respective societies in terms of labour activity (see Lenin, Vladamir. The Development of Capitalism in Russia. Moscow: Progress Publishers, 1899. and Mao Tse-Tung. 'Analysis of the Classes in Chinese Society.' in Selected Works of Mao Tse-Tung. Peking: Foreign Language Press, 1926).

${ }^{4}$ Clearly this welfare loss from supervision costs needs to be with balanced with the efficiency gains from the economies of scale found in many industries.

${ }^{5}$ The statistics from the sample suggested that 0.2 per cent of the households responding fit the characteristics of the capitalist landlord, 14.3 per cent were rich farmers, 29.2 per cent were family farmers, 8.7 per cent were poor peasants, and 35.9 per cent matched the description of landless labourers. The residual 11.7 per cent were made up of those who engaged in no income earning activity during the sample period, or were involved in all three of the income-earning activities in Roemer's model, a proposition which was excluded by Roemer's assumption that own labour and hired labour were perfect substitutes.

${ }^{6}$ In this model 'efficiency units' refers to a worker's potential productivity given his level of human capital; it is not related to the degree of effort used in work.

${ }^{7}$ The rationale for treating adult human capital as an exogenous endowment in this model is the following: First, because of the limited resources of most LDCs, opportunities for educational investment are far from evenly distributed across the population; the supply and location of educational institutions is heavily influenced by circumstance and political whim (Foster 1983). This is particularly the case in Guatemala. Moreover, in the narrower context of this research, since FUNDAP's stated objective is to lend equally freely to borrowers regardless of educational background, access to credit and educational level are independent of one another, and can be viewed as co-determinants of class structure membership.

${ }^{8}$ For notational simplicity the subscript $i$ will be dropped from this point forward although for clarity the subscript $j$ will continue to represent hired agents.

${ }^{9}$ The parameter $\theta$ reflecting uncertainty in production will be suppressed in the remainder of the analysis as it does not play a substantial role with the absence of risk-aversion in the utility functions of agents.

${ }^{10}$ One might think that recipients of FUNDAP loans might be a self-selected sample of aggressive entrepreneurs eager to expand their businesses relative to a more passive control group. However, during the survey, members of the control group in fact were highly enthusiastic about the possibility of receiving credit from FUNDAP, but to that point had been denied credit due to their location in areas yet unserved by the credit program.

${ }^{11}$ Since an entrepreneur's labour activity in firms with approximately five or more employees was observed to become primarily supervisory and administrative, these individuals were classified as $(0,0, s)$. 


\section{$\underline{\text { References }}$}

Bardhan, P., 1982, 'Agrarian Class Formation in India', Journal of Peasant Studies, Vol.10, pp.73-94.

Bardhan, P., 1984, Land, Labour, and Rural Poverty: Essays in Development Economics, New York: Columbia University Press.

Bardhan, P. (ed.), 1989, The Economic Theory of Agrarian Institutions, Oxford: Clarendon Press.

Eswaran, M., and A. Kotwal, 1986, 'Access to Capital and Agrarian Production Organization', Economic Journal, Vol.96, pp.482-98.

Roemer, J., 1982, A General Theory of Exploitation and Class, Cambridge: Harvard University Press.

Romer, P., 1990, 'Endogenous Technological Change', Journal of Political Economy, Vol.98, pp.71-102.

Stiglitz, J. E., 1974, 'Incentives and Risk-Sharing in Sharecropping.' Review of Economic Studies. Vol.41, pp.219-55.

Stiglitz, J. E. and K. Hoff, 1990, 'Imperfect Information and Rural Credit Markets-Puzzles and Policy Perspectives.' The World Bank Economic Review, Vol.4., pp.235-50.

Williamson, J. G., 1988, 'Migration and Urbanization.' in Hollis Chenery and T. N. Srinivasan, Eds., Handbook of Development Economics, New York: North-Holland.

World Bank, 1989, World Development Report 1989: Financial Systems and Development, New York: Oxford University Press.

Wright, E. O., 1997, Class Counts, Cambridge: Cambridge University Press. 